\title{
Advanced Coatings for Buildings
}

\author{
Aníbal Maury-Ramírez ${ }^{1, *}$, Inês Flores-Colen ${ }^{2, *}$ [i] and Hideyuki Kanematsu ${ }^{3, *}$ (i) \\ 1 Engineering Faculty, Universidad El Bosque, Edificio Fundadores 3er Piso, Av. Cra 9 No. 131 A-02, \\ Bogotá 111711, Colombia \\ 2 CERIS, DECivil, IST, Universidade de Lisboa, Av. Rovisco Pais, 1049-001 Lisboa, Portugal \\ 3 Department of Material Science and Engineering, National Institute of Technology (KOSEN), \\ Suzuka College, Suzuka 510-0294, Japan \\ * Correspondence: amaury@unbosque.edu.co (A.M.-R.); ines.flores.colen@tecnico.ulisboa.pt (I.F.-C.); \\ kanemats@mse.suzuka-ct.ac.jp (H.K.)
}

Received: 22 July 2020; Accepted: 24 July 2020; Published: 24 July 2020

\begin{abstract}
Based on five Special Issues in Coatings, this e-book contains a series of fifteen articles demonstrating actual perspectives and new trends in advanced coatings in buildings. Innovative materials and multiperformance solutions provide a basis, contributing also to better protection of buildings' surfaces during the service life, and users' wellbeing.
\end{abstract}

Keywords: protective coatings; air-purifying coatings; anti-fouling coatings; ultra-low biofouling coatings; biological coatings

\section{Introduction}

Based on the current need to achieve sustainable development, multiperformance coatings have been developed for building applications (new and existent ones) to improve durability and to achieve novel, sustainable and health functions. Although there are already some commercially available coating products on the market, their application in the construction sector is still not very common. With some exceptions, this situation is most probably due to the lack of reported scientific evidence and the fact that there are still numerous unanswered questions about the concept and application. Therefore, this e-book is aimed to provide recent research and works on the application potential of advanced coatings for buildings and intends to give new scientific insights into the interrelation between science, engineering, architecture and other disciplines by means of advanced techniques for coatings' characterization and their application.

\section{Multiperformance, Durable and Sustainable Coatings}

This e-book, entitled "Advanced Coatings for Buildings", contains a collection of five Special Issues consisting of fifteen articles which cover fundamental studies and applications of multiperformance coatings designed to improve durability and to achieve novel, sustainable and health functions in buildings. COVID-19 redefined the concept of sustainability, making crucial the inclusion of human health [1]. Therefore, solutions proposed by engineers, architects and scientists should be addressed, giving buildings innovative functions such as: air-purifying and fire-resistant properties, long-lasting aesthetical appearance, water resistance, anti-fouling and anti-microbial surfaces. The current threat of interacting with microorganisms also generates new challenges that must be acknowledged to improve human quality of life, for example, by developing biological coatings for buildings which can act as a thermal, moisture, noise, and electromagnetic barrier. On the urban scale, they might reduce the heat island effect and sewage system load, improve runoff water and air quality, and reconstruct natural landscapes including wildlife. In summary, this e-book on coatings compiles the following Special Issues 
demonstrating the bright future of advanced coatings for buildings: "Advanced Protective Coatings for Buildings" [2,3], "Nanocoatings with Air-Purifying Properties" [4-6], "Antifouling Coatings" [7-10], "Ultra-Low Biofouling Materials and Coatings" [11] and "Biological Coatings for Buildings" [12-16]. Going into detail, the Special Issues include the following topics:

- "Advanced Protective Coatings for Buildings": nanomaterial-based protective coatings, multifunctional coatings, bio-based protective coatings, smart protective coatings, sustainable protective coatings, low-embodied energy protective coatings, ecotoxicity on protective coatings, durable protective coatings and recycled protective coatings.

- "Nanocoatings with Air-Purifying Properties": comparison and assessment of the application potentials of novel nanocoatings for indoor and outdoor air purification.

- "Antifouling Coatings": coatings for commercial facilities, residential buildings, food processing, kitchens, baths and toilets, oil and water pipes.

- "Ultra-Low Biofouling Materials and Coatings": fundamentals and new concepts on ultra-low biofouling surface chemistries, novel nanostructured materials as coatings and coating additives, advancement in coating deposition technologies to improve coating antifouling performance, the self-assembly of chemistries and/or nanomaterials to fabricate antifouling thin films and coatings, advancements in understanding interfacial interactions between antifouling surfaces and microbial organisms.

- "Biological Coatings for Buildings": mechanical, thermal and hydraulic performance of biological coatings, modeling of biological coatings, life cycle assessment of biological coatings, construction of biological coatings and novel biological coatings.

Based on these interesting topics, we encourage you to read through this e-book and use the valuable information provided therein to help us move forward in the important area of multiperformance coatings with potential application in buildings for improving durability and to achieve innovative, sustainable and health functions. This approach certainly is a breakthrough to solve the current human threats for sustainable development during buildings' service life.

Funding: This research received no external funding.

Conflicts of Interest: The authors declare no conflict of interest.

\section{References}

1. Hakovirta, M.; Denuwara, N. How COVID-19 Redefines the Concept of Sustainability. Sustainability 2020, 12, 3727. [CrossRef]

2. Borsoi, G.; Esteves, C.; Flores-Colen, I.; Veiga, R. Effect of Hygrothermal Aging on Hydrophobic Treatments Applied to Building Exterior Claddings. Coatings 2020, 10, 363. [CrossRef]

3. Beh, J.H.; Yew, M.C.; Yew, M.K.; Saw, L.H. Fire Protection Performance and Thermal Behavior of Thin Film Intumescent Coating. Coatings 2019, 9, 483. [CrossRef]

4. Cruz-Pacheco, A.F.; Muñoz-Castiblanco, D.T.; Gómez Cuaspud, J.A.; Paredes-Madrid, L.; Parra Vargas, C.A.; Martínez Zambrano, J.J.; Palacio Gómez, C.A. Coating of Polyetheretherketone Films with Silver Nanoparticles by a Simple Chemical Reduction Method and Their Antibacterial Activity. Coatings 2019, 9, 91. [CrossRef]

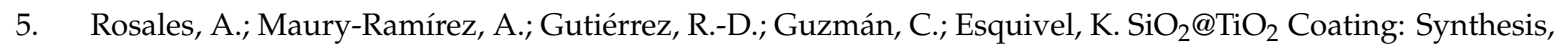
Physical Characterization and Photocatalytic Evaluation. Coatings 2018, 8, 120. [CrossRef]

6. Guzmán-Aponte, L.A.; Mejía de Gutiérrez, R.; Maury-Ramírez, A. Metakaolin-Based Geopolymer with Added $\mathrm{TiO}_{2}$ Particles: Physicomechanical Characteristics. Coatings 2017, 7, 233. [CrossRef]

7. Kanematsu, H.; Oizumi, A.; Sato, T.; Kamijo, T.; Honma, S.; Barry, D.M.; Hirai, N.; Ogawa, A.; Kogo, T.; Kuroda, D.; et al. Biofilm Formation of a Polymer Brush Coating with Ionic Liquids Compared to a Polymer Brush Coating with a Non-Ionic Liquid. Coatings 2018, 8, 398. [CrossRef]

8. Nguyen, M.D.; Bang, J.W.; Kim, Y.H.; Bin, A.S.; Hwang, K.H.; Pham, V.-H.; Kwon, W.-T. Anti-Fouling Ceramic Coating for Improving the Energy Efficiency of Steel Boiler Systems. Coatings 2018, 8, 353. [CrossRef] 
9. Zhang, M.; Wang, R.; Li, L.; Jiang, Y. Size Distribution of Contamination Particulate on Porcelain Insulators. Coatings 2018, 8, 339. [CrossRef]

10. Ba, M.; Zhang, Z.; Qi, Y. Fouling Release Coatings Based on Polydimethylsiloxane with the Incorporation of Phenylmethylsilicone Oil. Coatings 2018, 8, 153. [CrossRef]

11. Hecker, M.; Ting, M.S.H.; Malmström, J. Simple Coatings to Render Polystyrene Protein Resistant. Coatings 2018, 8, 55. [CrossRef]

12. Naranjo, A.; Colonia, A.; Mesa, J.; Maury-Ramírez, A. Evaluation of Semi-Intensive Green Roofs with Drainage Layers Made Out of Recycled and Reused Materials. Coatings 2020, 10, 525. [CrossRef]

13. Gutiérrez, R.-D.; Villaquirán-Caicedo, M.; Ramírez-Benavides, S.; Astudillo, M.; Mejía, D. Evaluation of the Antibacterial Activity of a Geopolymer Mortar Based on Metakaolin Supplemented with $\mathrm{TiO}_{2}$ and $\mathrm{CuO}$ Particles Using Glass Waste as Fine Aggregate. Coatings 2020, 10, 157. [CrossRef]

14. Verdier, T.; Bertron, A.; Erable, B.; Roques, C. Bacterial Biofilm Characterization and Microscopic Evaluation of the Antibacterial Properties of a Photocatalytic Coating Protecting Building Material. Coatings 2018, 8, 93. [CrossRef]

15. Naranjo, A.; Colonia, A.; Mesa, J.; Maury, H.; Maury-Ramírez, A. State-of-the-Art Green Roofs: Technical Performance and Certifications for Sustainable Construction. Coatings 2020, 10, 69. [CrossRef]

16. Illera, D.; Mesa, J.; Gomez, H.; Maury, H. Cellulose Aerogels for Thermal Insulation in Buildings: Trends and Challenges. Coatings 2018, 8, 345. [CrossRef]

(C) 2020 by the authors. Licensee MDPI, Basel, Switzerland. This article is an open access article distributed under the terms and conditions of the Creative Commons Attribution (CC BY) license (http://creativecommons.org/licenses/by/4.0/). 